\title{
The project of professional career orientation complex for ASD pupils based on virtual reality technologies
}

\author{
Ludmila V. Tokarskaia ${ }^{1 *}$, Tatiana $Y$. Bystrova ${ }^{2}$, and Elmira R. Valieva ${ }^{1}$ \\ ${ }^{1}$ Associate Professor of Psychological Department, Ural Federal University, Yekaterinburg, Russia \\ ${ }^{2}$ Professor of Cultural Studies and Design Department, Ural Federal University, Yekaterinburg, \\ Russia \\ ${ }^{3}$ Master in pedagogic, Ural Federal University, Yekaterinburg, Russia
}

\begin{abstract}
The paper analyses the application of virtual reality technologies to career guidance of children and adolescents with autism spectrum disorders (ASD). An overview of studies using virtual reality technologies conducted with children and adolescents with ASD, including diagnosis and teaching of schoolchildren with autism spectrum disorders, is made. The authors follow "The Theory of Central Coherence" by U. Frith, realizing symptoms of autism spectrum disorders not as disorders but as peculiar features and a special cognitive style. The study describes the features of vocational guidance of ASD individuals on the basis of the sources about the difficulties of people with ASD in the transition from school to secondary and higher education. The authors project of a complex vocational guidance using virtual reality technology for students with ASD introducing "a city-farmer" profession is represented. The tripartite structure of the vocational guidance complex is showed, the need for interaction of specialists with the parents of a child with ASD, as well as identification of "savant skills" at the first stage of career guidance work was emphasized. Examples of virtual spaces developed by one of the authors are given, with which people with ASD interact by the determination their possible professional trajectory. The tasks and responses of users in the vocational guidance complex for schoolchildren are described. A conclusion about the possibility of expanding the list of professions in the vocational guidance simulator for children with ASD is made.
\end{abstract}

\section{Introduction}

Autism spectrum disorders, or ASDs are impairments in social interaction characterized by behavior stereotypies and other manifestations. In the 2010s ASDs attract more and more active attention of researchers and practitioners of pedagogy, psychology, and medicine due to the growing prevalence of such disorders. The growing numbers of patients range from $0.07 \%$ to $1.8 \%[8 ; 15]$, and according to the World Health Organization, 1 out of 160

\footnotetext{
* Corresponding author: liydmil@mail.ru
} 
children have ASDs, that is, $0.6 \%$ of the entire child population of the Earth [7]. As a rule, ASD is diagnosed in a person in childhood, but persists throughout life. With the help of corrective methods, the manifestations of these disorders can be reduced [11].

According to Diagnostic and Statistical Manual of Mental Disorders (DSM), a human being with ASD symptoms suffers from three types of disorders: shortcomings in social sphere; shortcomings in the communication sector and the retardation in the development of speech; with stereotypies, or repetitive actions.

In order to get closer to understanding the mechanisms of the origin and course of autism spectrum disorders, researchers developed ASD theory, which explains the nature of ASD from different angles. The first theory is called the Psyche Model, or "The Theory of Mind", proposed by C. Baron-Cohen and U. Frith [3]. Then comes "The Theory of Executive Functions" [21]; and "The Theory of Mirror Neurons [25], and others. For this study, the key concept is "The Theory of Central Coherence" formulated by U. Frith [9, 13]. This theory treats symptoms of autism spectrum disorders not as disorders but as peculiar features and a special cognitive style. Children with ASD succeed in cooperation with units, however, they have difficulties with the perception of the whole. F. Happe characterizes this as a possible cognitive style of people with ASD [12]. In our opinion, this approach is the most effective for career guidance work with ASD children.

In general, career guidance includes work to identify a person's inclinations and talents for a specific field of the professional activity, as well as help in choosing a career path for people of all ages. In addition, it plays an essential role in a person's professional selfdetermination.

Although there is a growing interest of researchers and practitioners in designing career paths and assistance in professional self-determination ASD people, the number of career guidance tools available for this category of persons who can show them real opportunities to introduce the appropriate professions and the labor market is highly limited.

At this point vocational guidance experts widely use computer technologies and begin to apply the technologies of virtual reality (VR). Every year VR technologies develop faster, and, respectively, improves the quality of the virtual reality and its use becomes available to a larger number of people. Since the 2010s VR is actively introduced in the professional field of teachers, psychologists, and rehabilitators.

The analysis of sources on the topic shows the following problems of career guidance work in relation to ASD persons:

1) the discrepancy between current vocational guidance techniques and future labor markets;

2) the lack of accessible vocational guidance methods for people with health disabilities and in particular ASD people;

3) despite the state quotas for vacancies for persons with health limitations and ASD, there is still a lack of effective assistance to persons with disabilities and ASD in their professional self-determination.

The revealed complexity determines the actuality of professional orientation complex for pupils with ASD using virtually reality. It can be used in schools, universities, vocational guidance rehabilitation centers, non-profit organizations, employment services. The materials of professional orientation of individuals with ASD can further help the development of the models of their rehabilitation.

\section{Materials and methods}

The publications of Russian authors on the problem of organizing vocational guidance work with persons with health limitations and disabilities are quite numerous [16; 26; 34$]$. At the same time understanding that people with ASD need special support for their 
professional self-determination, in Russia came only in 2013, and have not yet been sufficiently developed in the practice of what is reflected in the insufficient number of publications $[18 ; 32]$. However, in the world science, this theme has been developed since 1960 s, and is acquiring a particular relevance in recent years.

The researchers note that people with ASD between the ages of 18 and 21, finishing school, experience enormous difficulties, since it is at this moment that professional selfdetermination should take place. According to the data of the National Society of people with ASD, $77 \%$ of them want to work, but fewer than one in five has a regular job [20].

In order to help with professional self-determination to ordinary people, there were created a lot of career guidance techniques, questionnaires, and career guidance centers that are beginning to deal with the problems of transition from school to college or institution of higher education to persons with disabilities. The studies that are analyzed by us further are devoted to the same topic.

C. Alverson and her co-authors determine what specific personal and social barriers are faced by young people with ASD while leaving school, and how to help them be successful in college [1]. They argue that communication and executive problems were created in school and continued in colleges. These barriers appear to limit the ability of persons with ASD to discuss academic goals and to participate fully in social activities related to higher education. The paper identifies five main factors influencing the success of the transition from school to college: intrinsic motivation to go to college; high awareness of disability; constant family support; coordinated transition planning; clear professional goals.

$\mathrm{S}$. Bell et al. also investigated the school-to-college transition of young people with ASD [4]. The aim of the study was to examine how the transition occurred in young people with ASD at two separate points in time: "before the transition", when they had a "desire" to move to higher education, and "after the transition", when whether or not they took a step towards higher education. The authors consider the little-studied issues related to the problems faced by students with ASD during the transition, the resources available to students with ASD and the means of support to adapt them to this moment, the experience of students with ASD in gaining access to secondary education. The study found that parental support may need to be especially active in the transition phase, to help young people with ASD to establish initial contact with the labor agency. Education programs and the evaluation criteria included in higher education courses should be reviewed, and for students with ASD there is a need for special recommendations.

The main conclusion made by the authors is that the development of professional selfdetermination skills should be encouraged as a key factor of success in higher education, which should begin in secondary school.

L.W. Briel and E.E. Getzel [5] using structured interview techniques, described the process of transition of individuals with ASD from senior high school to college or university; as well as the problems that arise during this transition. The sample consisted of 18 students with ASD from 18 to 43 years old, but the majority of the sample $(\mathrm{N}=17)$ were 18 to 24 years old. The results of the interviews give an idea of the training needs of students with ASD. Although the participants were at different stages of education and training for a career (from the first year to postgraduate), and attended college with various and programs and higher education across the state, they shared a common experience, containing in itself, in the first place, the need for support.

Most of the study participants sought information about their professional activities from a variety of people, including family members, as well as school and college staff. However, it turned out that career guidance centers are the least likely source of information and support for schoolchildren with ASD, since they do not work with young people with ASD and cannot help them with professional self-determination, since the staff of these centers are not trained to work with people with ASD. Considering the features, in 
the centers, as a rule, there are no specialized programs and techniques which are adapted for patents with ASD.

Basically, students with ASD generally do not have enough knowledge or context that would help them in choosing a profession and a better understanding of the potential working environment which they might enter. In addition, they identified a need to expand learning opportunities through information interviews, internships or mentoring, and work experience opportunities.

Based on their findings, the authors conclude that it is important to develop strategies to help graduates with ASDs explore their interests, strengths and opportunities for practical application of academic knowledge before starting their professional career.

In general, research on the problem of vocational guidance for persons with ASD was carried out on small samples. These experiments were not standardized and, in general, were descriptive in nature without entering the model of vocational guidance work. These studies did not use modern digital technologies. Even abroad, where the movement towards the development of vocational guidance work with ASD individuals started in the 1960 s, it is very difficult to get adequate help in professional self-determination of such students. In Russia, this issue is even more burning. To make the transition from high school to college or university less traumatic and problematic, vocational guidance work with ASD students should be initiated in high school and include familiarity with the context of their future professional activity.

\section{Results}

Based on data on the maximum difficulties of people with autism spectrum disorders between the ages of 18 and 21 years, associated with entering "adult" life, data on the use of virtual reality in the diagnosis and teaching of schoolchildren with autism spectrum disorders, and based on the analysis of many career guidance techniques, we propose to provide vocational guidance for schoolchildren with ASD using virtual reality.

For this, we have developed and presented a project of a vocational guidance complex using virtual reality technology for schoolchildren with autism spectrum disorders, which has methodological and visual components. A plan of a vocational guidance complex and a number of locations in virtual reality have been developed to help a student with ASD choose a suitable profession. One of such trajectories is shown in the text.

\section{Discussion}

\subsection{Possible directions of vocational guidance for schoolchildren with ASD}

Before the start of activities on career guidance of a child with ASD during the dynamic observation of the process of education and training it is required to determine the current and dynamic parameters of his/her social development, communication, speech, intelligence, affective sphere, and regulation-volitional characteristics [18].

In addition, when providing vocational guidance to schoolchildren with ASD, it is necessary to take into account the possible presence of "savant skills" [9;27;32;33], which can manifest themselves in the form of special abilities in one or several areas of knowledge (music, painting, mathematics, computer science, etc.), and contrast with the "general limitedness of personality", which is explained by the Theory of Central Coherence. 
Employers also point out that ASD patients have qualities which are as follows: reliability, responsibility, a smaller tendency to absenteeism, as well as special attention to detail that is an important professional quality for some professions [19].

S. Morozov et al. provide guidelines for the beginning of vocational guidance work with individuals with ASD [18], as well as professional management and work with this group of individuals.

\subsection{Using VR in the diagnosis and teaching of schoolchildren with autism spectrum disorders}

The ideas that virtual reality can be a promising technology in psychological, pedagogical and correctional support of children with ASD emerged in the early 2000s. At the same time, researchers conducted the first studies of the behavior of such children in a virtual reality $[6 ; 22-24]$. In spite of the fact that some children had difficulty in interaction with the virtual environment (mainly children with low verbal intelligence and executive functions [22]), the whole virtual environment had a positive influence on them (despite the concerns of researchers that the virtual environment would not be adequately perceived by children with ASD), and, therefore, work in this direction was continued.

Due to the specifics of autism spectrum disorders, most research has focused on the development of social skills in children with ASD in virtual reality.

Therefore, already in 2007, the work of T. Self and coauthors, including the experimental and control groups, showed that teaching children with ASD the skills of safe behavior in the event of a fire or tornado is much more effective if it was carried out in virtual reality [28]. The study by D. Strickland et al. also demonstrated the effectiveness of virtual reality in teaching children with ASD the skills of safe behavior [31]. And thanks to the application, portable glasses (Google Cardboard) and smartphones (iPhone X), adolescents with ASD in three weeks learned socially acceptable behavior at the airport and on board an airplane [17].

In addition to teaching aids, virtual reality can also be used as a diagnostic technology. V. Jyoti and U. Lahiri studied the severity of the mechanism of joint attention in children with ASD in virtual reality using an avatar, not a real person [14]. M. Smith et al. developed virtual reality training exercises «Virtual Reality Job-Interview Training» (VRJIT), aimed at preparing persons with disabilities to take part in professional activities [30]. In 2020, the authors adapted a training program for people with ASD, mainly of young age (18-22 years old), aimed to help them at the time of transition from high school to college or university [29].

Summarizing data study first, we can say that over the last 15 years, virtual reality has proven itself as a promising and efficient technology in the work with children and adults with ASD. Using virtual reality technology can effectively teach an ASD child a desired behavior in a specific situation (a fire, an airplane flight, and others.). The technology can teach a child to develop social and communicative skills to assess cognitive parameters and assist in professional self-determination ... In addition, virtual reality arouses interest, positive emotions, positive motivation and a playful spirit in children with ASD. The technology of virtual reality offers an important advantage for individuals with ASD: it creates a secured space with the possibility of controlling the degree of severity of sensory input without external distractions. 


\subsection{The project of a vocational guidance complex using virtual reality technology for students with ASD}

For the design of a professional orientation complex we conducted the analysis of the most popular methods used in Russian secondary schools, as well as modern computer tests used in vocational guidance centers and universities which are as follows: the methodological questionary "Differential-diagnostic questionnaire" (DDQ) by E. A. Klimova; the methodological test "Defining professional personality type by J. Holland"; the methodological questionary "Questionnaire of professional inclinations by L.A. Jovaiša"; the methodological questionary "Professional Readiness Questionnaire (PRQ) by L. N. Kabardova" ; the methodological test "A Professional Orientator", developed under the leadership of A.G. Shmelev in the Center of Testing and Development of the Moscow State University "Humanities' technologies", and others. The latter procedure involves standardized tests, and advanced technology. The results of the students who took the test is detailed, but at the same time it moves away from the imposition of a profession, it only indicates the vector of their possible development. In our opinion, it is this format can present vocational guidance work in the modern world, where career guidance can be done not only with the help of computer-based testing, but also by means of virtual reality technology.

In virtual reality, it is possible:

- to simulate a specific working situation for any profession, allowing you to immerse yourself in it, feel yourself in the profession, which can influence the awareness of choice;

- using specially created situations, to develop meta-subject competences (ability to learn, ability to solve problems, independence in performing actions) in the process of performing any activity in virtual reality;

- to carry out a comprehensive study using specially created tasks;

- to create an absolutely safe space with the ability to adjust the severity of sensory stimuli, which is very important for people with ASD;

- to create a database of the peculiarities of the passage of situations, on the basis of which studies of problems related to the vocational guidance of persons with disabilities in virtual reality can be carried out.

However, the virtual reality technology has some limitations:

1) the impact of a long stay in virtual reality of people with disabilities has not been sufficiently studied, the risk of cyber disease is high;

2) the technology is expensive;

3) there is a difficulty in implementation of an individual approach necessary when working with people with disabilities;

4) there is a complexity of realization of the most career-oriented environment in virtual reality due to large labor-intensive work.

These limitations can be overcome in the ways which are as follows:

1) before starting the program it is necessary to make a study, during which it will be revealed exactly how virtual reality affects individuals with ASD and what time they need to adapt to this environment;

2) with the more intensive development of virtual reality technology, its cost will decrease;

3) the technology of virtual reality will be combined with other methods of the vocational guidance complex (personal consultations, questionnaires of parents, etc.), which will allow for an individual approach. 


\subsubsection{The features of the implementation of a vocational guidance complex method using virtual reality technology for schoolchildren with ASD}

The method is designed for children with autism spectrum disorders, enrolled in high school (5-8 grades), with intact intellect. The choice of this school age is caused by the fact that in this period is already possible to start to think about future profession. There is also enough time to develop the necessary skills before high school graduation. Such professional work in elementary school is too early (in elementary school children may play appropriate games, informing them about the different occupations), and in high school too late (in high school it is already necessary to prepare pupils for specific exams and study the characteristics of the existing labor market). In addition, if such vocational guidance work is conducted with ASD children, it will decrease the likelihood of problems in the period between leaving the high school and entering college or university, of which many researchers wrote $[1 ; 4 ; 5]$.

The career guidance methodology in virtual reality consists of three phases and lasts with one child from a week to several months, since all three phases include determining a set of actions, without which the work will not be effective and person-centered, and these actions cannot be realized in a short amount of time.

\subsubsection{A short plan of the vocational guidance complex}

The plan takes into account not only the characteristics of virtual reality, but also user scenarios. Therefore, it pays great attention to joint actions, adaptation of a student with ASD to new circumstances. There is a "right for error" here, which the developers of the universal design concept strongly point out, and the possibility of going through the career guidance trajectory again.

The preparatory stage includes the points which are as follows:

1) Meeting a child and his/her parents (legal representatives);

2) The diagnostic assessment of the child (the study of his/her ASD history, the assessment of ASD manifestations):

3) Detection of the presence/absence of "Savant's skills" and learning his/her interests through an interview/questionnaire, and an interview/questionnaire to parents (legal representatives).

4) Based on the identified interests and abilities, the expert offers one or several professions suitable for the ASD person. The professions are selected from the list of professions compiled on the basis of the Atlas of new professions and trades recommended for ASD persons compiled by T. Grandin [10]. The child will get acquainted with the chosen professions in virtual reality.

2. The main stage:

1) The immersion in virtual reality of a selected profession / business (several sessions), including the preparation for dealing with VR; adaptation to VR; the immersion in VR.

2) The objective evaluation (the results of VR assignments) and the child's subjective (profession / businesses' assessment) factors.

The session of vocational guidance in the virtual reality environment lasts 20 minutes, during which the child is immersed in a situation specially selected for his/her profession, in which he examines the situation and performs a variety of tasks related to the specific activities of this profession. The activities are offered in a game format. More information about this the stage will be written further with the example of a specific profession. As a rule, 20 minutes is not enough to get acquainted with the profession, so this stage includes several sessions over several days. 
Later the expert asks the child about his/her attitude to this profession after the VR session and whether he/she would like to try any other profession. Also, with the help of computer processing, the success of the child's assignments $s$ in virtual reality is assessed.

3. Final stage:

1) Making a conclusion about the recommended profession/businesses and recommendations for improving any skills;

2) Further support. After the end of the career-oriented procedure, the contact with the child and his/her parents does not end there. At any time, they can again turn to the expert regarding any of the emerging issues, for example, the help with finding the right clubs, internships, or areas of training.

\subsubsection{Description of the work of a vocational guidance complex method through thee example of the city-farmer profession}

According to the Atlas of new professions, a city-farmer is "a specialist maintaining agricultural farms on the roofs of buildings, or skyscrapers in big cities," [2]. He needs the skills which are as follows: a good knowledge of botany and agricultural technologies; a skill to handle complex technical devices; basic knowledge of economy and management. For the profession, it is also required to have such qualities as responsibility, patience, and tolerance for routine work.

The analysis of the literature shows, that this occupation is accessible to an ASD person with without mental retardation with preserved or impaired verbal speech. For example, ASD people can handle plants and animals well, so the profession of a city farmer may be suitable for them.

In 2018, on the basis of the Ural project shift in the health-center "Tavatui", a pilot version of the virtual space for the city farmer profession was developed. It included two versions: indoors (Fig. 1, a) and on the roof of the building (Fig. 1, b). Later these locations will be finalized.

When the child is immersed in virtual reality, he first sees a video segment, which focuses on the profession of a city-farmer, its features and relevance.

Then the child enters the first room, where he/she is invited to look around. The child can interact with various virtual objects, for example, to open the cupboard to get a white coat - the uniform of the city-farmer (when the child gets the coat, he seems to be putting it on and sees before him his hands in white sleeves of his coat), opens or closes the window to inspect the plants and so on. During this time, the child gets the sense of presence in the VR through the interaction with virtual objects. After 3-5 minutes, instructors begin to give him tasks related to the activities of a city-farmer in a training and game format. The text tasks appear on the display, which is located on the wrist of the virtual hand (if a child has reading problems, the task is read out aloud), and the objects featuring in the task are being highlighted. 


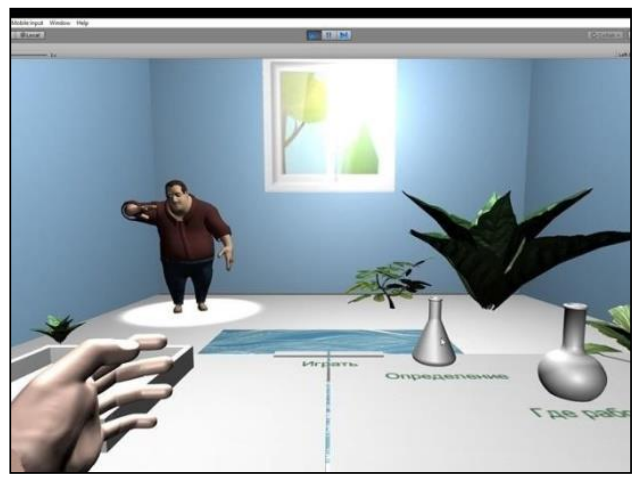

a.

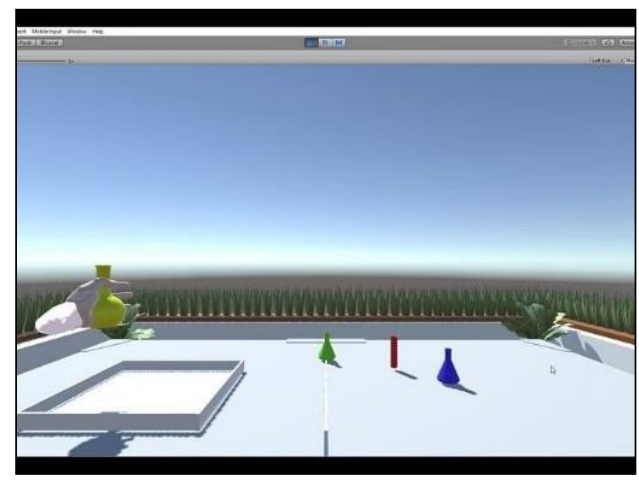

b.

Fig. 1. Screenshots from the pilot development of the City Farmer profession guidance complex method in virtual reality: 1.a) indoor location; 1.b) the location on the roof of the building. The author's original development.

Task 1. You need to mix a hydroponic solution of several ingredients in different proportions. The information about the necessary ingredients and proportions is given out in a visual form on the display.

If the child did the right thing, and the solution changes color, he gets a few points as a reward. If the child did not manage the task after the first attempt he/she is given one more attempt.

Task 2. The solution must be added to a special hydroponic system. The sequence of actions is also first shown on the display. If the child does the right thing, a green light turns on, and the child gets more points. Otherwise, the light bulb does not turn on, so the child is given a new attempt.

Task 3. The child must turn on the hydroponic system, do the settings, corresponding the features of plants. To find out which settings correspond to which plants, the child needs to refer to the virtual encyclopedia.

When the settings are completed, the child turns on hydroponic plant system, and the plants in it become brighter - this means that the task is done. The child gets points and a "city farmer" badge.

If the child fails to complete the tasks within 20 minutes, he continues to do them during the next session.

As a result, the child gets the basic knowledge about the profession of a city-farmer, some knowledge of hydroponic plants, as well as improving the ability to learn. Gamified elements (the points and the badge) increase the child's motivation to complete the tasks. Depending on the results of the session, the expert may recommend or not recommend the profession as an option for the future of the ASD child.

\section{Conclusion}

In the course of the Ural design shift we formulated the idea, developed the design, and proposed a trial 3-D environmental model for the profession of "a city-farmer" to Unity platform. In 2020, it was planned to continue the development of the model on the basis of the Institute of Radio Electronics and Information Technologies of UrFU in the format of a design workshop, but due to the epidemiological situation in Russia and the world, the development was suspended. 
The project to create a vocational guidance complex using virtual reality for ASD schoolchildren is long-term, as it includes many stages and the need to attract a large number of specialists from various fields: pedagogy, psychology, IT and design. The project is interdisciplinary, but also very actual, and its implementation will be a step towards solving the problem of vocational guidance of ASD individuals and, in general, will enable them to include them in active social life.

In addition, the data obtained from the use of vocational guidance techniques in virtual reality for persons with ASD can be used to study the mechanism of career guidance for other categories of persons with disabilities, as well as to assess the quality of the technique itself.

\section{References}

1. C.Y. Alverson, L.E. Lindstrom, K.A. Hirano, High school to college: Transition experiences of young adults with autism. (FOCUS) 1(34): 52-64 (2019).

2. New Professions Atlas. Date Views 10.05.2020 atlas100.ru.

3. S. Baron-Cohen, A.M. Leslie, U. Frith, Does the autistic child have a "theory of mind", Cognition, 1(21): 37-46 (1985).

4. S. Bell, C. Devecchi, C.Mc. Guckin, M. Shevlin, Making the transition to postsecondary education: opportunities and challenges experienced by students with ASD in the Republic of Ireland. European Journal of Special Needs Education, 1(32): 54-70 (2017).

5. L.W. Briel, E.E. Getzel, In their own words: The career planning experiences of college students with ASD. Journal of Vocational Rehabilitation, 3(40): 195-202 (2014).

6. L. Deligiannidis, G. Weheba, T. Self, Utilizing Virtual Reality for Autism Treatment. CISST: 248-253 (2004).

7. M. Elsabbagh, G. Divan, Y. Koh, Y.S. Kim, S. Kauchali, C. Marcín, C. Montiel-Nava, V. Patel, C.S. Paula, C. Wang, M.T. Yasamy and E. Fombonne, Global prevalence of autism and other pervasive developmental disorders. Autism Res., 3(5): 160-179 (2012).

8. E. Fombonne, Epidemiology of pervasive developmental disorders, Pediatr. Res, 6(65): 591-598 (2009).

9. U. Frith, Autism: Explaining the Enigma. Oxford (1989).

10. T. Grandin, Developing Talents: Careers for Individuals with Asperger Syndrome and High-Functioning Autism. AAPC Publishing; Updated, Expanded Edition 185 p. (2008)

11. E.L. Grigorenko, Rasstroistva autisticheskogo spektra. Vvodnyi kurs. Uchebnoe posobie dlia studentov [Autism spectrum disorders. Introductory course. Study guide for students]. Publishing house "Praktika". 280 p. (2018)

12. F. Happe, Autism: cognitive deficit or cognitive style? Trends in Cognitive Sciences, 6(3): 216-222 (1999).

13. F. Happe, U. Frith, The Weak Coherence Account: Detail-focused Cognitive Style in Autism Spectrum Disorders. J. Autism Dev. Disord. 1(36): 5-25 (2006)

14. V. Jyoti, U. Lahiri, 2020. Human-computer interaction based joint attention cues: implications on functional and physiological measures for children with autism spectrum disorder. Comput. Hum. Behav, 104: 106-163 (2020) 
15. Y.S. Kim, B.L. Leventhal, Y.J. Koh, E. Fombonne, E. Laska, E.C. Lim, K. Cheon, S. Kim, Y. Kim, H. Lee, D. Song and R.R. Grinker, Prevalence of autism spectrum disorders in a total population sample. Am. Journal Psychiatry, 168(9): 904-912 (2011)

16. I.L. Litvinenko, L.D. Kiianova, A.V. Gerasimov, 2018. Sistema upravleniia professionalnoi orientatsii obuchaiushchikhsia s invalidnostiu v RF [The system of management of vocational guidance of students with disabilities in the Russian Federation]. Sostoianie i perspektivy razvitiia inkliuzivnogo obrazovaniia v Respublike Kalmykiia [State and prospects for the development of inclusive education in the Republic of Kalmykia], 1: 4-12.

17. I.T. Miller, B.K. Wiederhold, C.S. Miller, M.D. Wiederhold, Virtual Reality Air Travel Training with Children on the Autism Spectrum: A Preliminary Report. Cyberpsychology, Behavior, and Social Networking, 1(23): 10-15 (2020)

18. S.A. Morozov, T.I. Morozova, B.V. Beliavskii, 2016. Nekotorye voprosy professionalnoi orientatsii podrostkov i vzroslykh s rasstroistvami autisticheskogo spectra [Some vocational guidance issues for adolescents and adults with autism spectrum disorders]. Autizm i narusheniia razvitiia [Autism and developmental disorders], 3(14): 3-20.

19. N. Murray, M. Hatfield, M. Falkmer, T. Falkmer, Evaluation of career planning tools for use with individuals with autism spectrum disorder: a systematic review. Research in Autism Spectrum Disorders, 26: 188-202 (2016)

20. National Autistic Society. Date Views 03.05.2020 autism.org.uk.

21. O'Hearn, K., M. Asato, S. Ordaz and B. Luna, Neurodevelopment and executive function in autism. Development and psychopathology, 4(20): 1103-1132 (2008)

22. S. Parsons, P. Mitchell, A. Leonard, Do adolescents with autistic spectrum disorders adhere to social conventions in virtual environments? Autism, 1(9): 95-117 (2005)

23. S. Parsons, P. Mitchell, A. Leonard, The use and understanding of virtual environments by adolescents with autistic spectrum disorders, Journal of Autism and Developmental disorders, 4(34): 449-466 (2004)

24. S. Parsons, P. Mitchell, A. Leonard, Virtual environments for social skills training: comments from two adolescents with autistic spectrum disorder. Computers \& Education, 2(47): 186-206 (2006)

25. V.S. Ramachandran, L.M. Oberman, Broken mirrors. Scientific American, 5(295): 6269 (2006)

26. E.S. Romanova, B.M. Kogan, E.S. Svistunova, E.V. Ananeva, Spetsifika proforientatsionnoi raboty s detmi i podrostkami imeiushchimi OVZ [Specificity of vocational guidance work with children and adolescents with disabilities]. Uchimsia sotrudnichat: Kompleksnyi podkhod k proforientatsii i profkonsultirovaniiu podrostkov s ogranichennymi vozmozhnostiami zdorovia [Learning to cooperate: An integrated approach to career guidance and vocational counseling for adolescents with disabilities], M.: Publishing Center "Academy": 16-23 (2012)

27. K. Scheuffgen, F. Happé, M. Anderson, U. Frith, High “intelligence”, low “IQ”? Speed of processing and measured IQ in children with autism. Development and Psychopathology, 1(12): 83-90 (2000)

28. T. Self, R. Scudder, G. Weheba, D. Crumrine, A virtual approach to teaching safety skills to children with autism spectrum disorder. Topics in Language disorders (TLD), 3(27): 242-253 (2007)

29. M.J. Smith, R.M. Pinto, L. Dawalt, J.D. Smith, K. Sherwood, R. Miles, T. Frazier, Using community-engaged methods to adapt virtual reality job- interview training for 
transition-age youth on the autism spectrum. Research in Autism Spectrum Disorders, 71: 101-498 (2020)

30. Smith, M.J., M.F. Fleming, M.A. Wright, A.G. Roberts, L.B. Humm, D. Olsen and M.D. Bell, Virtual reality job interview training and 6-month employment outcomes for individuals with schizophrenia seeking employment. Schizophr. Res, 1-3 (166): 86-91 (2015)

31. D.C. Strickland, D. McAllister, C.D. Coles, S. Osborne, An evolution of virtual reality training designs for children with autism and fetal alcohol spectrum disorders (TLD), 3 (27): 226 (2007)

32. L.V. Tokarskaia, A. N. Trubitsyna, Issledovanie sposobnostei i interesov detei s rasstroistvami autisticheskogo spektra [Research of the abilities and interests of children with autism spectrum disorders]. Izvestiia Uralskogo federalnogo universiteta Ser 1 Problemy obrazovaniia nauki i kultury [The Proceedings of the Ural Federal University. Series 1. Problems of education, science and culture], 4 (180): 121-129 (2018)

33. D.A. Treffert, The idiot savant: a review of the syndrome, 572 (1988)

34. V.V. Tkacheva, I.V. Evtushenko, Obosnovanie modeli proforientatsionnoi raboty s litsami s ogranichennymi vozmozhnostiami zdorovia so slozhnym defektom [The substantiation of the model of career guidance work with persons with disabilities with a complex defect]. Sovremennye problemy nauki i obrazovaniia [Modern problems of science and education], 5: 214 (2016) 